\title{
Microporosity of BIF hosted massive hematite ore, Iron Quadrangle, Brazil
}

\author{
CÉSAR A.C. VARAJÃO ${ }^{1}$, ARY BRUAND, ${ }^{2}$ ERICK R. RAMANAIDOU ${ }^{3}$ \\ and ROBERT J. GILKES ${ }^{4}$ \\ ${ }^{1}$ DEGEO, Escola de Minas, Universidade Federal de Ouro Preto, \\ Campus Morro do Cruzeiro, 35400 Ouro Preto, Brazil \\ ${ }^{2}$ ISTO, Université d'Orléans, Géosciences, BP 6759, 45067 Orléans Cedex 2 - France \\ ${ }^{3}$ CSIRO - Division of Exploration and Mining, Private Bag. P.O., Wembley - WA 6014 - Australia \\ ${ }^{4}$ Soil Science and Plant Nutrition, The University of Western Australia, Nedlands, WA 6907, Australia \\ Manuscript received on September 27, 2000; accepted for publication on September 6, 2001; \\ presented by A.J. MELFI
}

\begin{abstract}
Massive hematite ore (MHO) is a special high-grade iron ore, used as lump ore in the process of obtaining direct reduction iron (DRI). The influence of porosity on the reducibility of MHO from the Capitão do Mato Mine (Iron Quadrangle, Brazil) was investigated using optical and scanning electron microscopes on drill core and open pit samples.

Hematite is the main component of the samples and occurs as granular crystals $(10 \mu \mathrm{m})$, microplates $(1 \mu \mathrm{m})$ and euhedral martite (10 to $30 \mu \mathrm{m}$ ). Quartz, maghemite, kenomagnetite and goethite are minor components. Primary micropores ( $\AA$ to $1 \mu \mathrm{m}$ ) are associated with microplaty crystals that fill cavities between granular hematite. Secondary micropores ( $\AA$ to $5 \mu \mathrm{m}$ ) related to euhedral martite crystals, are the most important.

The total porosity of weathered samples, measured using nitrogen adsorption and mercury injection, attains values up to $11 \%$, whereas unweathered samples have a porosity less than $2.5 \%$. Reducibility is strongly enhanced by porosity, but inhibited by structure (bedding).
\end{abstract}

Key words: BIF, porosity, massive hematite ore, direct reduction iron, reducibility.

\section{INTRODUCTION}

For many years, iron ores were classified only by their chemical composition. In addition to the $\mathrm{Fe}_{2} \mathrm{O}_{3}$ content, the quality of the ore was defined by its contents of $\mathrm{P}_{2} \mathrm{O}_{5}, \mathrm{SiO}_{2}, \mathrm{Al}_{2} \mathrm{O}_{3}$, and loss on ignition (LOI). The steelmaking industry now requires additional data on physical properties (size-range, fines, mechanical strength), metallurgical properties (reducibility, swelling, clustering or sticking and

Correspondence to: César Augusto Chicarino Varajão

E-mail: varajao@degeo.ufop.br thermal decrepitation) and geological characteristics (mineralogical composition and grain size of iron-oxide minerals, texture, structure, porosity and permeability).

Reducibility is defined as the measure of the rate at which a given iron ore or agglomerate will reduce under arbitrary and fixed temperature and gas composition (Feinman and MacRae 1999). The direct reduction (DR) process, used to obtain the direct reduced iron (DRI), is defined as any process in which metallic iron is produced by the reduction of iron ore below the melting temperature of any mate- 
rials involved (Sikabin 1980). The worldwide DRI production has increased since 1970 and reached 37.1 million metric tons in 1997 (MIDREX 1999) which represent roughly $5 \%$ of the world steel production. The demand for DRI continues to increase due to its multiple application in the steel industry, including electric arc and basic oxygen furnaces (Kopfle 1999).

The main world iron resources occur as banded iron formation (BIF) deposited mainly between 2.5 and 1.8 Ga (Klein and Beukes 1992). Mineralogically, the term BIF is used to differentiate the oxide facies (James 1954) consisting dominantly of hematite, magnetite and chert from siderite and silicate facies.

The iron content of BIFs can increase after deposition either by replacement of gangue minerals by goethite (Morris 1980) or their dissolution by weathering under appropriate climatic conditions (Dorr 1964). The replacement of gangue minerals by hematite can be explained by hydrothermal alteration (Gruner 1937, Guild 1953, Barley et al. 1999, Powell et al. 1999), metassomatism during metamorphism (Dorr and Barbosa 1963, Dorr 1965), or supergene enrichment followed by burial metamorphism (Morris 1980, 1985). In either case, if the enrichment of iron in the primary deposit attains appropriate values, the BIF is an ore for the steel industry.

The ideal iron ore for use in the DRI process should be porous in order to obtain rapid and substantial reducibility (Poveromo and Swanson 1999). In the furnace, the lump ore is submitted directly to the injection of reducing gases, under high temperature $\left(750^{\circ} \mathrm{C}\right)$, the rate of reduction depending on the interaction between the gases and the oxides. A clear evaluation of the extent and nature of the porosity in iron ore will be in monitoring and understanding its behavior in the DRI process.

Banded iron formations that underwent medium to high-grade metamorphic conditions have a low porosity. Low-grade metamorphism and low compaction rates may preserve a primary porosity. On the other hand, during metasomatism and hy- drothermal alteration, the primary sedimentary textures may be partially or completely modified by replacement, resulting in a secondary porosity. Additionally, considering that BIFs were exposed to various climatic conditions throughout the geological time, they may have undergone congruent (Melfi et al. 1976) or incongruent (Ramanaidou et al. 1996) dissolution, resulting in textural changes and formation of secondary porosity.

The aim of this paper is to present results of the investigation of the microporosity of a particular BIF iron ore, known as "hematita compacta" (massive hematite) from the Capitão do Mato Mine, Iron Quadrangle, Minas Gerais State, Brazil (Figure 1). This ore is used as lump ore to obtain direct reduction iron (DRI) and contains high proportion of hematite and less than $2 \%$ of quartz.

Dutta et al. (1972) and Xavier (1994) compare massive ore with other iron-ore types (friable, schistose, brechia) and concluded that the high porosity of friable ores is the main factor determining its better reducibility, as also described by Leone et al. (1981). On the other hand, Poveromo and Swanson (1999) state that the low porosity of massive iron ore is due to the tight-packing of granular hematite. Muniz et al. (1992) and Xavier (1994) determined that reducibility of these ores depends on the crystal size and its distribution within the ore, as well as on the nature of bedding. Thus, ores homogeneouslytextured, very fine-grained $(<10 \mu \mathrm{m})$ and lacking bedding are more easily reduced.

\section{LOCATION AND GEOLOGY OF THE CAPITÃO DO MATO MINE}

The Capitão do Mato Mine is located in the northwestern portion of the Iron Quadrangle, $15 \mathrm{~km}$ South of Belo Horizonte, the capital of the Minas Gerais State (Figure 1). The climate of the region is tropical, with dry winters and wet summers, and annual mean rainfall of $1700 \mathrm{~mm}$. The mine belongs to Minerações Brasileiras Reunidas S.A. - MBR, with production starting in 1997.

This region is one of the world's classic geological sites, contains one of the most important 

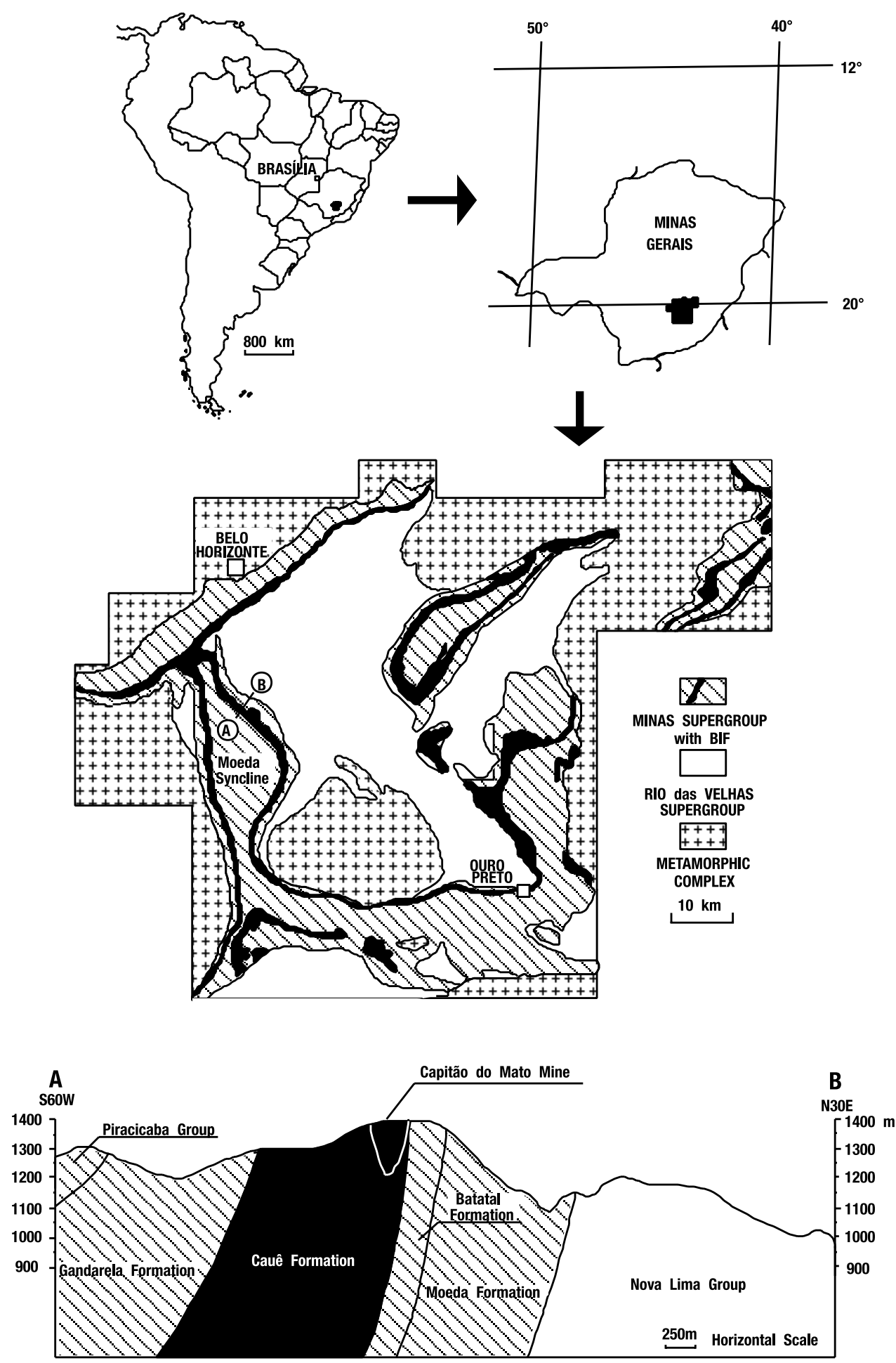

Fig. 1 - Location, geologic map (Marshak and Alkmim, 1989) and geologic section of the Capitão do Mato Mine (geology from Pomerene 1964), Iron Quadrangle, Minas Gerais State, Brazil. 
Brazilian iron ore reserves (40\%), being responsible for $70 \%$ of country's annual production (Table I). In the worldwide market Brazil contributes with $32 \%$ of lump ore, of which the Iron Quadrangle is responsible for $29 \%$.

\section{TABLE I}

Annual production of iron ore and lump ore from the Iron Quadrangle, Brazil and World. (*) DNPM (1999); (**) Poveromo and Swanson (1999).

\begin{tabular}{c|c|c|c}
\hline & & $\begin{array}{c}\text { Iron } \\
\text { Ore }(*)\end{array}$ & $\begin{array}{c}\text { Lump } \\
\text { Ore }(* *)\end{array}$ \\
\hline & & 145 & 2.45 \\
Production & Iron Quadrangle & 195 & 2.64 \\
$10^{6} \mathrm{t}$ & Brazil & 850 & 5.82 \\
\hline
\end{tabular}

The Iron Quadrangle is located on the southern part of the São Francisco Craton (Almeida 1977). The regional geology was (Figure 1) initially described by Harder and Chamberlin (1915) and subsequently reviewed by Dorr (1969), Marshak and Alkmim (1989). Three geological units are recognized: (1) the Metamorphic Complexes, which consist of Archaean tonalite to granitic gneisses and migmatites; (2) the Rio das Velhas Supergroup, a greenstone belt rock sequence; and (3) the Minas Supergroup, which consists of Early Proterozoic, low-grade metamorphic metasedimentary formations, including the here studied banded iron formation, locally called itabirites.

After deposition, the Minas Supergroup underwent into large-scale synclines and anticlines extensional deformation (Endo and Nalini 1992, Chemale Jr. et al. 1994), and metamorphism under greenschist facies conditions. During the Braziliano Cycle (750-450m.y.) its eastern part was affected by a deformation due to compression (Marshak and Alkmim 1989, Machado et al. 1992), under which metamorphic facies reached the amphibolite facies. The studied ore samples were collected at the western side of the Iron Quadrangle, where metamorphic facies is of the greenschist facies.

The high-grade hematite ore was defined as non-hydrated, ranges from hard and dense to powdery, and contains more than $66 \% \mathrm{Fe}$. According to the degree of packing of the hematite grains, the ore is classified into hard, friable (soft) and intermediate types. Soft hematite ore is commonly schistose in the eastern portions of the Iron Quadrangle, and contrast with the massive and granular ores from the west. The reserves of high-grade ore are in range between 100 and 400 million tons (Dorr 1965).

The Capitão do Mato Mine is located at the reverse flank of the Moeda syncline (Figure 1). Weathering of the BIF, which results mostly in the dissolution of quartz, reaches only about $20 \mathrm{~m}$ deep in the massive hematite ore-body (canga), but elsewhere it can be followed to a deepth of 200m (Figure 2a).

The genesis of the massive hematite ore has been subject of a long and deep controversy. The earliest interpretations (Harder 1914, Harder and Chamberlin 1915, Sanders 1933) favored a syngenetic model, followed by hydrothermal (Guild 1953) and synmetamorphic metasomatic models (Dorr and Barbosa 1963, Dorr 1965) models. New petrological evidence (Varajão et al. 1997), points towards a gradational contact between $\mathrm{MHO}$ and the host BIFs. Moreover, previous researches on structural data (Xavier 1994, Zavaglia 1996) described evidence of a sedimentary control based on the lens shape of the ore bodies.

\section{MATERIALS AND METHODS}

Thirteen samples from the weathering profile exposed in the open pit of the Capitão do Mato mine, and 72 deep samples from drill-cores were collected (Figure 2b), 19 of which were selected to measure porosity. Before further steps, polished sections were described by means of an optical microscope and SEM. Bulk chemical analyses data were obtained by ICP and reducibility Midrex Linder Test (MLT) at $750^{\circ} \mathrm{C}$ performed at the MBR laboratories, according ISO 11258.

Carbon-coated polished sections of ore were examined under a scanning electron microscopy (Philips 505) at the Centre for Microscopy and 

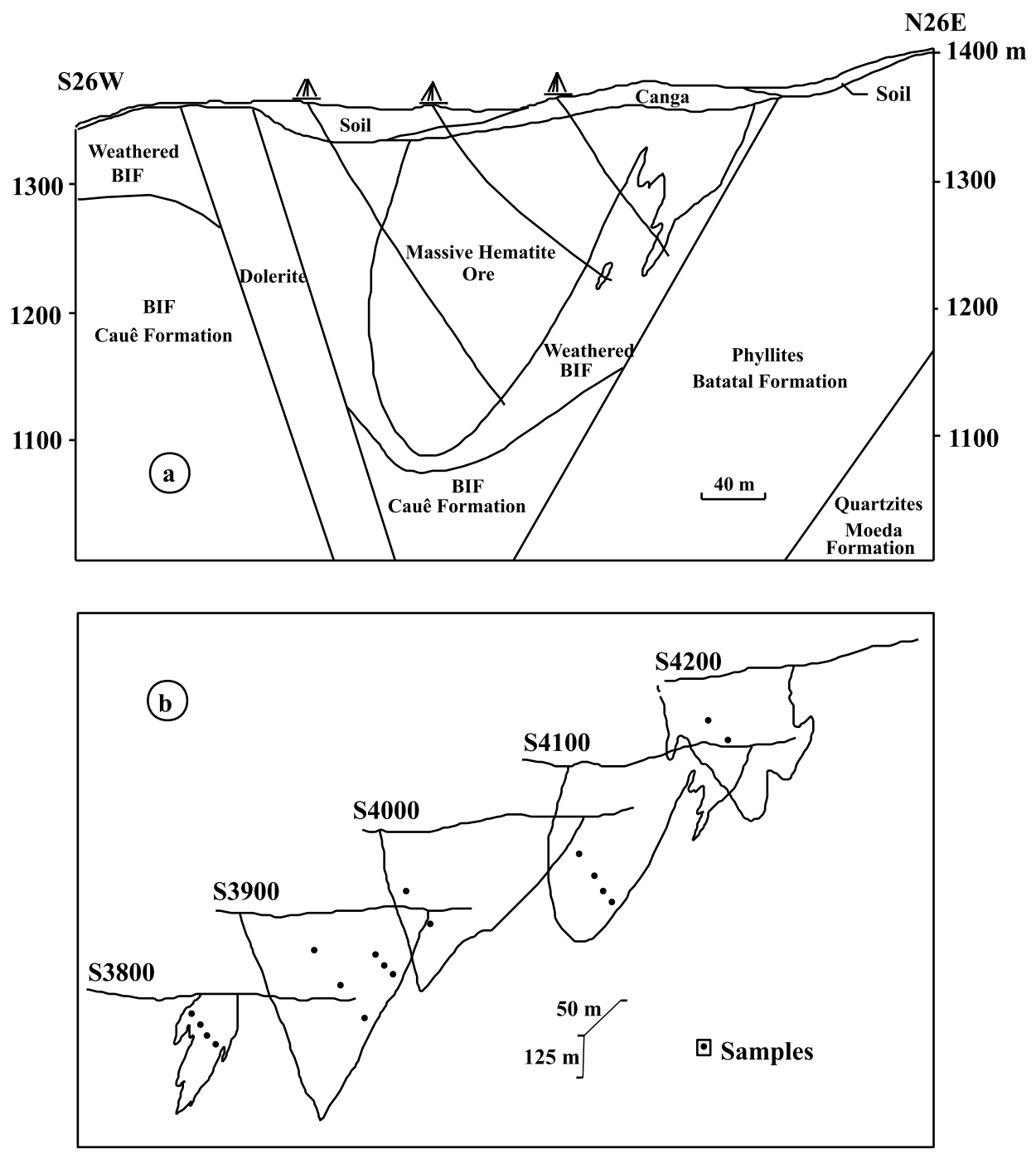

Fig. 2 - (a) Local geologic section of the Capitão do Mato Mine, showing the massive hematite ore intercepted by boreholes and (b) the localization of the samples chosen for porosity measurements.

Microanalysis, University of Western Australia CMM-UWA, using secondary and backscattered electrons at $15 \mathrm{kV}$ and $30 \mathrm{kV}$ and a working distance ranging from 9.5 to $12 \mathrm{~mm}$. Bulk chemical data of the samples were obtained by means of a JEOL JSM 6400 EDS instrument at the CMM-UWA.

Bulk density $\left(\mathrm{g} / \mathrm{cm}^{3}\right)$ was determined using the kerosene method (Monnier et al. 1973). Porosity was determined by braking the samples with a hammer to obtain one 9.5 to $31.5 \mathrm{~mm}$ and another 1.4 to $3.35 \mathrm{~mm}$ size-classes. The first class was used in the DRI experiments and the determination of the porosity by mercury injection. The second was used for nitrogen desorption porosimetry, due to the equipment limitations.

The pore-size distribution was determined by combining mercury porosimetry and nitrogen desorption methods. The first involves the measurement of the pressure required to force mercury into the pores of a dry sample and its volume intruded 
at each pressure. Assuming cylindrical pores, the relationship between pore diameter $(D$, in $\mathrm{nm})$ and applied pressure $(P$, in $\mathrm{MPa})$ is given by the expression:

$$
D=-410^{3} \gamma \cos \theta / P
$$

where $\gamma$ is the surface tension of mercury and $\theta$ its contact angle with the solid material. Mercury intrusion measurements were made with a $9310 \mathrm{Mi}-$ cromeritics porosimeter at the Institute Nationale de la Recherche Agronomique - INRA, Orléans, France, that operates up to a maximum pressure of $200 \mathrm{MPa}$ (Fiès and Bruand 1998). Values for $\gamma$ and $\theta$ were $0.484 \mathrm{~N} \mathrm{~m}^{-1}$ and $130^{\circ}$, respectively, which yield pore volume $\mathrm{V}$ distribution with equivalent diameters between $6.2 \mathrm{~nm}$ and $2.5 \mu \mathrm{m}$. Measurements were made in duplicate on about $15 \mathrm{~g}$ of material.

The nitrogen desorption method was applied to samples 1.4 to $3.35 \mathrm{~mm}$ in size. This method involves the determination of the desorption branch of the nitrogen isotherm, used to relate the amount of nitrogen lost in a desorption step to the average size of pores emptied in the step. A pore loses its liquid adsorbate, called the core of the pore, at a particular relative pressure $p / p_{0}$, related to the core radius $(r)$ by the Kelvin equation (Sills et al. 1973):

$$
\frac{R T}{V} \ln \frac{p}{p_{0}}=-\frac{2 \lambda \cos \theta}{r},
$$

where $R$ is the gas constant, $T$ is the absolute temperature, $\lambda$ is the surface tension, and $V$ is the molar volume of liquid nitrogen. After the evaporation of the core bulk liquid, a layer of adsorbed nitrogen remains on the wall of the pore. This layer becomes thinner by successively lowering the pressure. The total amount of gas desorbed in each step (core + wall layer) was measured by the BJH method, incorporated into a Gemini III 2375 V5.00 equipment, at the Soil Science and Plant Nutrition Department (UWA). The results yield pore equivalent diameters between 0.2 and $20 \mathrm{~nm}$. Measurements were made on about $3.5 \mathrm{~g}$ of material.

\section{RESULTS}

\section{Massive Hematite Ore}

Massive hematite is high-grade ore (Dorr 1965), hard, granular, dense and more or less bedded (Figure $3 \mathrm{a}, \mathrm{b}$ ). It has a very particular chemical composition, as at the Capitão do Mato Mine, with $68 \%$ of $\mathrm{Fe}$ and less than $3 \%$ of quartz and other gangue minerals (Table II). MHO breaks into irregular blocks commonly with conchoidal fractures (Figure 3a).

The mineralogical composition of $\mathrm{MHO}$ is very specific. Hematite is the main component and occurs as granular $(10 \mu \mathrm{m})$, microplaty crystals $(1 \mu \mathrm{m})$ and euhedral martite (10 to $30 \mu \mathrm{m})$ formed after magnetite. Quartz, maghemite, kenomagnetite (intermediate phase between magnetite and maghemite; Morris 1980, 1985) and goethite are minor components.

The alternation between hematite rich layers and martitized magnetite-hematite layers ( $\mathrm{mm}$ to $\mathrm{cm}$ ) is frequent (Figure 3b) and it defines the bedding $\left(\mathrm{S}_{0}\right)$, which coincides with a metamorphic foliation $\mathrm{S}_{1}$ (Endo and Nalini 1992, Chemale Jr. et al. 1994, Alkmim and Marshak 1998). Quartz grains are locally present along the contact between these layers and may also be occasionally abundant in the hematite layers but were not observed in the martitized magnetite-hematite layers.

In general, the hematite crystals are subparallel to the bedding $\left(\mathrm{S}_{0}\right)$ and schistosity $\left(\mathrm{S}_{1}\right)(\mathrm{Fig}$ ure 3c), but are discordant near and at the axial zone of folds, where the $S_{1}$ becomes oblique to $S_{0}$ (Figure $3 \mathrm{~d}$ ). The recrystallization of granular hematite into platy crystals $(10 \mathrm{~mm})$, locally formed $\mathrm{mm}$ to $\mathrm{cm}$ thick layers parallel to $S_{1}$ or $S_{2}$. Normally, microplaty hematite $(1 \mathrm{~mm})$ is euhedral, non-oriented and occurs between granular hematite.

Textural relationships, observed under microscope, show that magnetite occurs in two varieties. The most common is homogeneously equigranular $(10 \mathrm{~mm})$ and parallel to $S_{0} \equiv S_{1}$. The less common is euhedral (10 to $30 \mu \mathrm{m}$ ) and parallel to $S_{2}$. As a rule, magnetite crystals are partially or totally martitized (Figures 3c and 3e). Partially martitized 
TABLE II

Average chemical composition of 21 samples from the Capitão do Mato Mine used for porosity measurements.

\begin{tabular}{c|c|c|c|c|c|c}
\hline & $\mathrm{Fe}$ & $\mathrm{P}_{2} \mathrm{O}_{5}$ & $\mathrm{Al}_{2} \mathrm{O}_{3}$ & $\mathrm{SiO}_{2}$ & $\mathrm{MnO}_{2}$ & LOI \\
\hline Average & 68.30 & 0.041 & 0.64 & 0.73 & 0.02 & 0.66 \\
$\sigma$ & 0.90 & 0.034 & 0.47 & 0.47 & 0.012 & 0.78 \\
\hline
\end{tabular}

crystals often contain a core of kenomagnetite (Figure $3 \mathrm{f}$ ), rarely maghemite and locally goethite (Figure $3 g$ ).

At least two generations of quartz were identified. The first (5 to $10 \mu \mathrm{m}$ ) is parallel to $S_{0} \equiv S_{1}$, and interpreted as recrystallized during metamorphism (Figure 3e). The second is remobilized into veins ( $\mu \mathrm{m}$ to $\mathrm{mm}$ wide), where the quartz grains (5 to $30 \mu \mathrm{m}$ ) are associated with microplaty hematite $(<1 \mu \mathrm{m})$ and a haematitic-goethitic matrix.

Under high magnification, polished sections of the studied sampes reveal that non-oriented microplaty hematite and euhedral martite contain abundant micropores, which also occur in the weathered facies, but mainly in fractures.

The massive nature and the small size of crystals of the ore inhibited a good impregnation. Therefore, during polishing some crystals were pulledout, leading to a false porosity (Figure 3c). However, SEM images of rock fragments provided a good tool for obtaining and understanding the nature of the micropores.

\section{NATURe OF Pores}

Scanning electron images of MHO samples show two classes of pore-size: micropores (from $\AA$ to $75 \mu \mathrm{m})$ and macropores (> $75 \mu \mathrm{m})$. The micropores are associated with primary microplaty hematite, secondary euhedral martite and goethite. The macropores occur in weathered samples, fractures and shear zones. Macropores were not the subject of this study.

Micropores associated with euhedral martite vary in size from $\AA$ to several $\mu \mathrm{m}$. Some are trian- gular, due the replacement of magnetite by hematite (Figure 3h). Euhedral martite also contains rounded and irregular pores $(1 \mu \mathrm{m})$, which seem to be interconnected (Figures $4 \mathrm{a}, \mathrm{b}$ ). The micropores associated with nonoriented hexagonal microplaty hematite occur within intragranular spaces between granular hematite. Their size range from $\AA$ to $1 \mu \mathrm{m}$ (Figures $4 \mathrm{c}, \mathrm{d}$ ) and they also seen to be interconnected. However, the intragranular spaces themselves are not interconnected.

Many of the micropores are weathering features due to dissolution (Figure 4e) or associated with goethite (Figure 4f). They are interconnected, very irregular and range in size from $\AA$ to $75 \mu \mathrm{m}$.

Combined data from electron and optical microscopy provided considerable insight into the nature of the porosity. However, due to lacking of contrast, the samples images could not be analyzed in appropriate software to evaluate the total porosity and pore size distribution.

\section{Porosity Data}

The total porosity $\left(\mathrm{N}_{2}\right.$ desorption $+\mathrm{Hg}$ injection) plotted against bulk density of MHO samples is shown in Figure 5a. Samples with higher density have lower total porosity.

The fresh or slightly weathered samples have a porosity less than $2 \%$, whereas in weathered samples can reach $11 \%$. These values are similar to those obtained by Dutta et al. (1972) for Indian iron ores, in which the porosity ranges between $3.5 \%$ and $7.1 \%$.

A comparison between the values of pore volume obtained from nitrogen desorption $(D<$ 
a

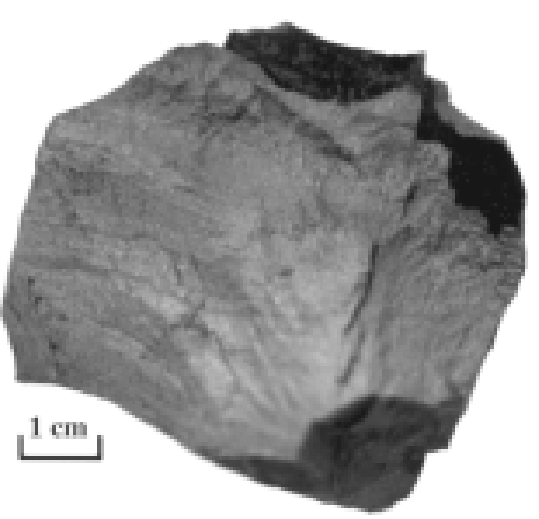

c

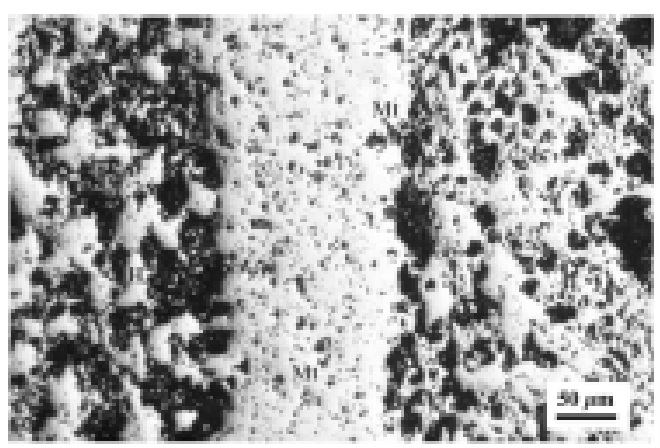

e

10 on

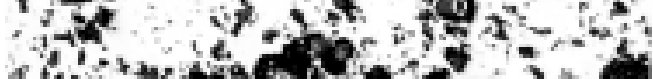

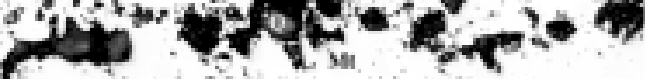

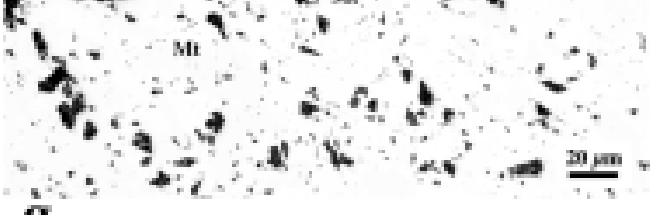

g

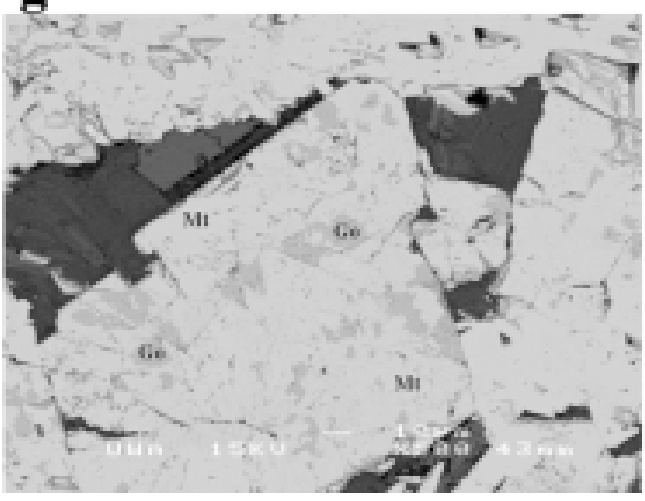

b
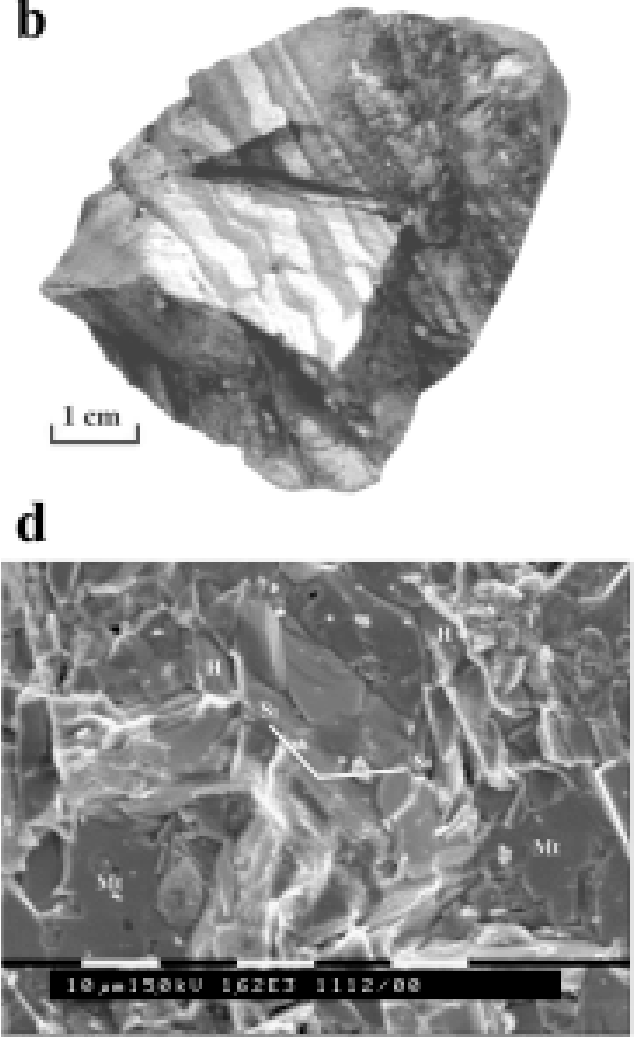

f

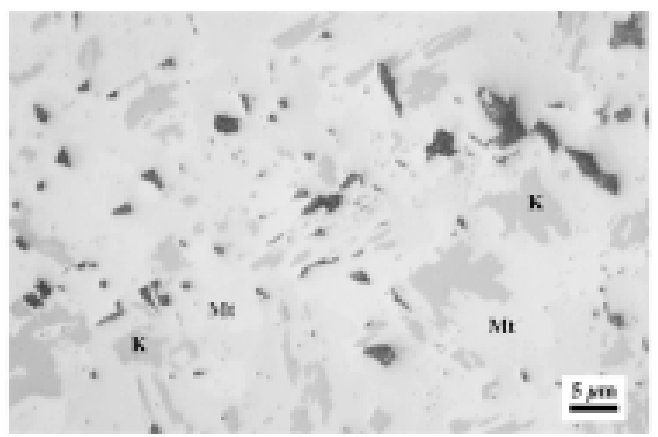

h

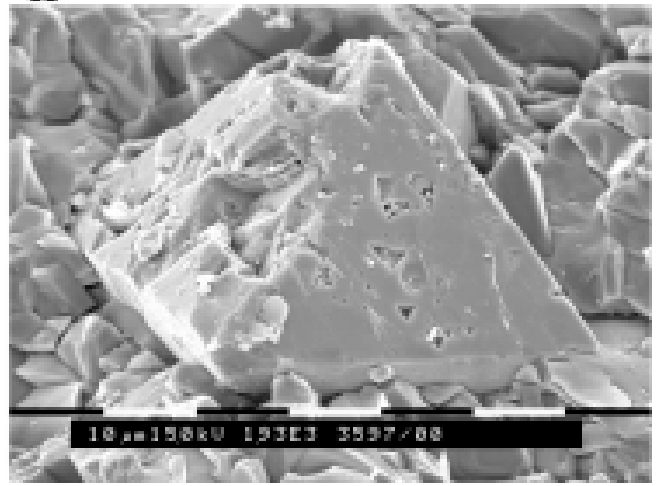


Fig. 3 - (a) Sample of hematite ore massive; (b) reflected natural light micrograph of massive hematite ore, showing the alternation between martite-rich and martite/hematite-layers layers reflecting bedding $\left(\mathrm{S}_{0}\right)$; (c) reflected natural light micrograph of massive hematite ore, showing the alternation between martite-rich layers $(\mathrm{mm}$ to $\mathrm{cm}$ ) and martite/hematite-rich layers; (d) reflected natural light micrograph showing the contact between a martite-rich and hematite layers, and the presence of some quartz crystals; (e) SEM micrograph showing the contact between a martite rich layer and a martite/hematite layer $\left(\mathrm{S}_{0}\right)$ and hematite crystals slightly and discordantly orientated $\left(\mathrm{S}_{1}\right)$; (f) SEM micrograph showing martitized magnetite with cores of kenomagnetite; (g) SEM micrograph, backscattered electrons image, showing of martitised magnetite with cores of goethite; (h) SEM micrograph showing triangular micropores in an euhedral martite crystal.

$200 \AA$ ) with the total porosity (Figure 5b), indicates that in slightly weathered samples (total porosity $<2.5 \%$ ) small pores account for to $80 \%$ of the total porosity. However, in more weathered samples, the volume of small pores is less significant, account for less than $20 \%$ of the total porosity.

\section{POROSITY AND REDUCIBILITY}

The reducibility of MHO as compared to total porosity (Figure 5c) clearly shows that the studied samples comprise two populations. One is narrowly grouped about a porosity $<2.5 \%$ and excellent and has an excellent reducibility (96 to 97\%). The other population is widely scattered and its porosity correlates positively with reducibility, by which low porosity $(2.5 \%)$ samples have a low reducibility $(90 \%)$, and samples with higher porosity (10\%) have an excellent reducibility (94 to 96\%). The occurrence of these two populations suggests that porosity is not the only factor that control the reducibility.

\section{DISCUSSION}

The micropores associated with euhedral magnetite grains were interpreted as due to a congruent dissolution of the kenomagnetite cores leading to skeletal martite, and therefore, a microporosity (Varajão et al. 1996). However the presence of goethite in some cores of martitized magnetite suggests an intermediate step in the weathering of magnetite (Morris 1980, 1985). On the other hand, the transformation of magnetite into martite requires a volume reduction of about $8.4 \%$ (Davis et al 1968), resulting in the formation of microfractures at the mag- netite/martite, paths for fluid penetration (Lagoeiro 1998). The martitization is here interpreted as due to weathering and, thus, the pores inside the martitized magnetite as a secondary feature.

The micropores that resulted from weathering, in spite of being well interconnected, are of minor importance, because they are limited to the boundaries of fractures. Thus, the massive character is the main feature of the MHO.

The micropores in association with microplaty hematite are not interconnected and must be considered as a metamorphic feature. They were formed under greenschist facies conditions to which the western part of the Iron Quadrangle underwent, and where the Capitão do Mato Mine is located. These pores, unlike those discussed above, should be interpreted as primary.

MHO reducibility values from the Capitão do Mato Mine are similar to those from the neighbor Mutuca and Tamanduá mines (Xavier 1994, Zavaglia 1996), respectively of $91.6 \%$ and $94.56 \%(\sigma=$ 2.87\%). The minimum acceptable value of MHO lump ore in DRI is $90 \%$ (Xavier 1994).

In previous researches, the comparison between porosity and reducibility was always made on friable ores, in which porosity can reach $30 \%$ (Dutta et al. 1972) even 35\% (Varajão et al. 2000). The low porosity $(0.3$ to $11 \%)$ and the two porosity $\times$ reducibility populations of the MHO (Figure 5c) needs additional factors other than porosity to explain its high reducibility.

Textural variations, structure (bedding, schistosity) and porosity are geological factors that also 
a

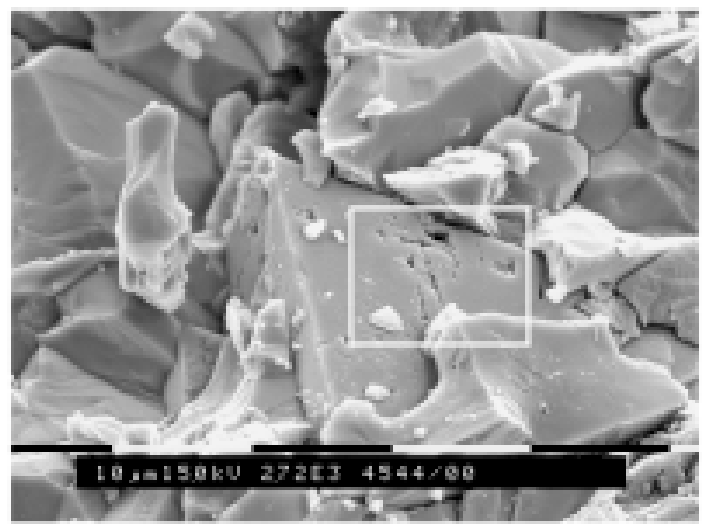

c

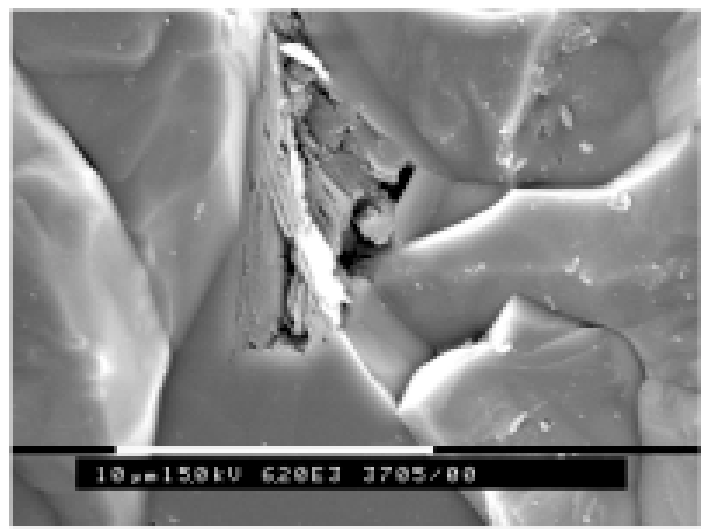

e

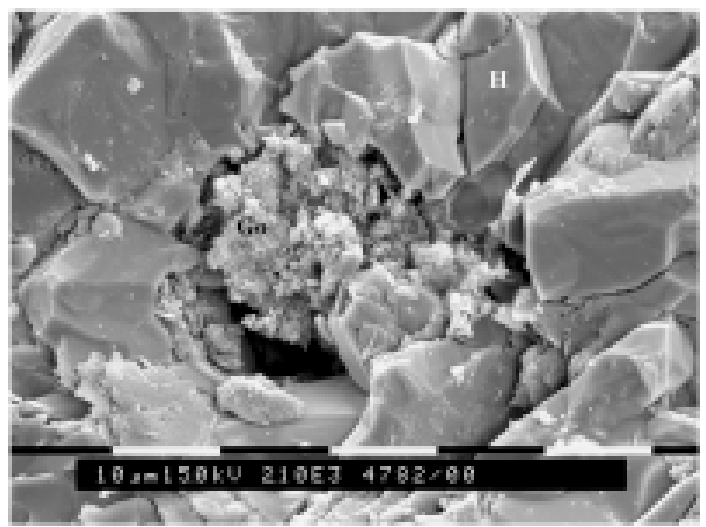

b

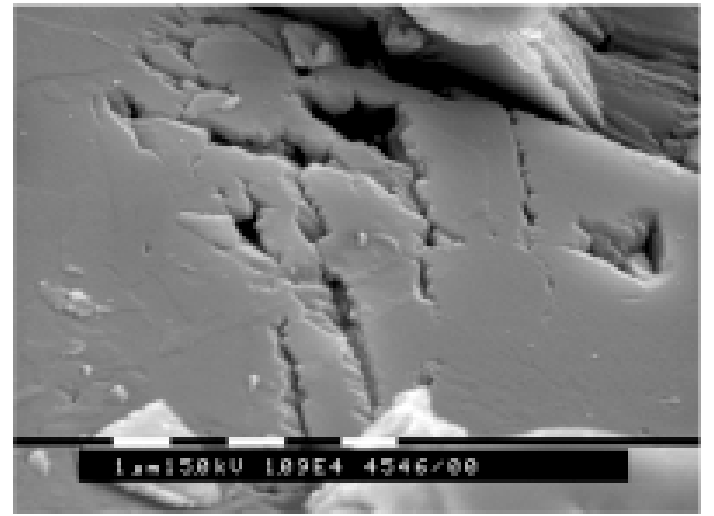

d

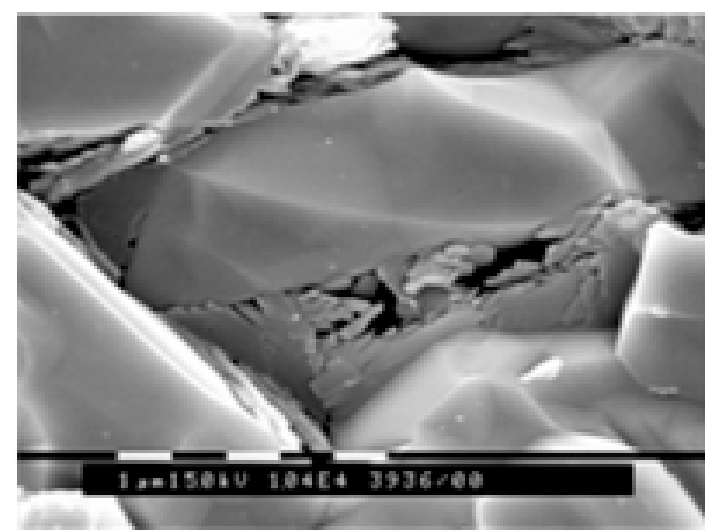

f

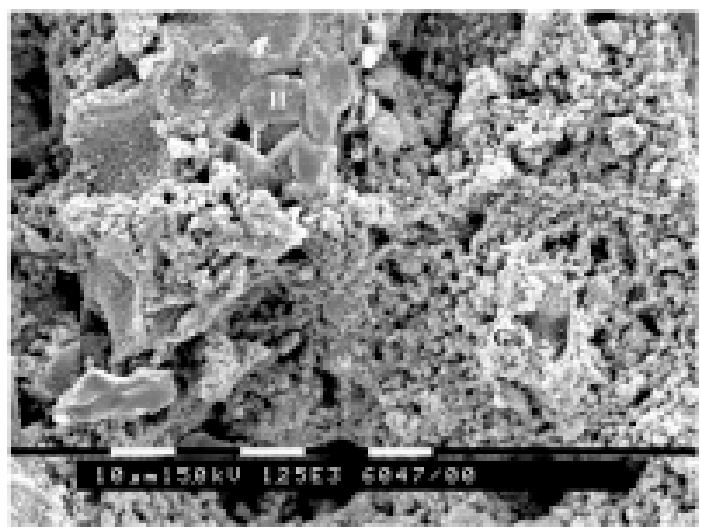

Fig. 4 - (a and b) SEM micrographs showing rounded micropores associated with an euhedral martite crystal, (d and e) SEM micrographs showing micropores in non-orientated microplaty hematite; (f) SEM micrograph showing micropores in dissolution cavity, partially filled by secondary goethite; (g) SEM micrograph showing micropores associated with goethite. 

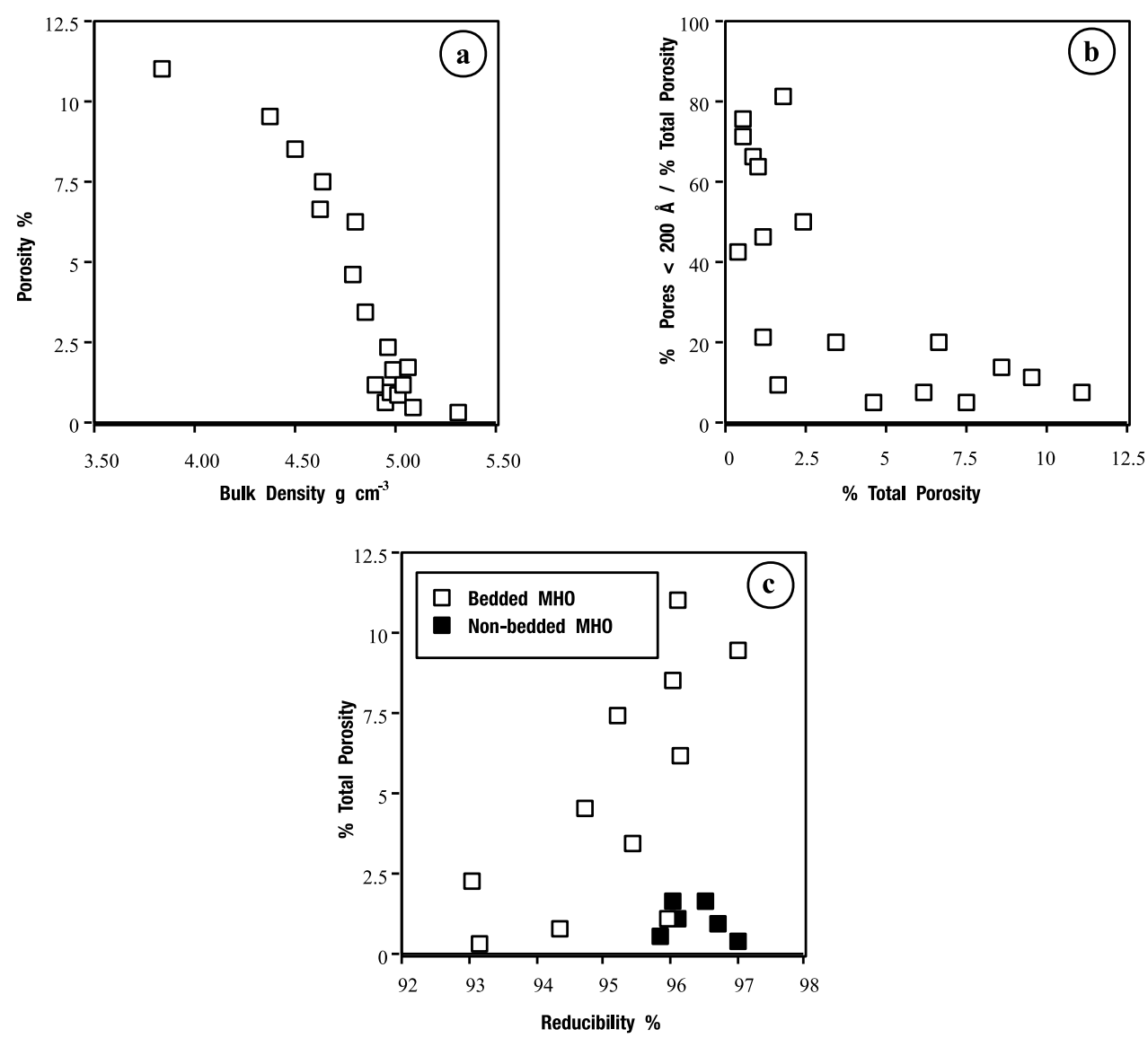

Fig. 5 - (a) Comparison between porosity (\%) and bulk density $\left(\mathrm{g} \mathrm{cm}^{-3}\right)$ of MHO; (b) comparison between total porosity (\%) and the pore volume obtained by nitrogen desorption $(D<200 \AA)(\%)$; (c) comparison between porosity (\%) and reducibility (\%) of bedded and non-bedded MHO.

influence reducibility (Muniz et al. 1992, Xavier 1994). Considering the dominant small crystal size of the MHO from the Capitão do Mato Mine, an important additional variable is the presence or the absence of bedding. In fact, adding the "bedding factor' to compare porosity x reducibility (Figure 5c), indicates that the best reducibility values ( 96 to $97 \%$ ) result mostly from non bedded samples, which correspond to the first population. On the other hand, samples presenting a clear and well defined bedding, mostly correspond to the second population and in which the reducibility depends on porosity. These results illustrate the importance of both porosity and structure (bedding) on the reducibility of MHO.

\section{CONCLUSION}

The study of the microporosity of MHO from the Capitão do Mato Mine reveals that unweathered materials has a low porosity (less than $2.5 \%$ ), but in weathered samples it may reach $11 \%$. Lithologically the MHO can exhibit more or less well defined bedding, due to the alternating martite and hematiterich layers. The pores in MHO are mainly due to the presence of euhedral martite and to microplaty hematite. Additional pores are due to weathering.

Reducibility of MHO for DRI is highly dependent on porosity of the bedded samples. However, samples without bedding were only slightly porous, yet exhibited excellent reducibility. 
These results are very useful for the exploitation of the Capitão do Mato Mine and other similar mines, allowing the prediction of ore behavior during DRI production and provide a basis for ore blending based on the knowledge of the physical and mineralogical properties of the ore.

\section{ACKNOWLEDGMENTS}

This paper results from a collaborative research program supported by FAPEMIG (Fundação de Amparo à Pesquisa do Estado de Minas Gerais). We thank R.C. Morris for discussions of the petrological aspects and also MBR (Minerações Brasileiras Reunidas S.A.) for geological data and field work support.

\section{RESUMO}

O minério de hematita compacta (MHC) é um tipo de minério de ferro de alto grau usado como minério granulado na obtenção do ferro via redução direta (DRI). A influência da porosidade sobre a redutibilidade do MHC da Mina de Capitão do Mato (Quadrilátero Ferrífero, Brasil), foi investigada em amostras de furos de sonda e de afloramentos da mina, usando-se microscópio óptico e eletrônico de varredura.

Hematita é o principal componente mineralógico e ocorre sob diferentes formas: granular $(10 \mu \mathrm{m})$, microtabular (1 $\mu \mathrm{m})$ e euédrico (10 a $30 \mu \mathrm{m})$. Quartzo maghemita, kenomagnetita e goethita são componetes menores.

Microporos primários ( $₫$ to $1 \mu \mathrm{m}$ ) associam-se a cristais de hematita microtabular, que preenchem espaços entre cristais de hematita granular. Microporos secundários ( $\AA$ to $5 \mu \mathrm{m}$ ), relacionados com os cristais de martita euédrica, são os mais importantes.

A porosidade total das amostras do MHC, medida através dos métodos de adsorção de nitrogênio e injeção de mercúrio, atingiu valores de até $11 \%$ para amostras intemperisadas. Amostras não alteradas de MHC têm porosidade menor que $2,5 \%$. Verificou-se que a porosidade incrementa a redutibilidade, enquanto que a estrutura (bandamento) tem uma influência negativa na redutibilidade do MHC durante o DRI.
Palavras-chave: BIF, porosidade, hematita compacta, redução direta, redutibilidade.

\section{REFERENCES}

Alkmim FF and Marshak S. 1998. Transamazonian Orogeny in the Southern São Francisco Craton Region, Minas Gerais Brazil: evidence for a Paleoproterozoic collision and collapse in Quadrilátero Ferrífero. Precamb Res 90: 29-58.

Almeida FFM. 1977. O Craton São Francisco. Rev Bras Geoc 7: 349-364

Barley ME, Pickard AL, Hangemann SG and FolKERT SL. 1999. Hydrothermal origin for the 2 bilion year old Mount Tom Price giant ore deposit, Hamersley Province, Western Australia. Min Dep 34: 784789.

Chemale Jr F, Rosiére CA and Endo I. 1994. The tectonic evolution of the Quarilátero Ferrífero, Minas Gerais, Brazil. Precamb Res 65: 25-54.

Davis BL, Rapp Jr G And Walawender MJ. 1968. Fabric and structural characteristics of the martitization process. Am J Sci 266: 482-496.

DNPM. 1999. Departamento Nacional da Produção Mineral. Commodity Summaries. www.dnpm.gov.br/dnpm eco.html.

DorR JVN. 1964. Supergene iron ores of Minas Gerais, Brasil. Econ Geol 59: 1203-1239.

DORR JVN. 1965. Nature and origin of the high-grade hematite ores of Minas Gerais, Brazil. Econ Geol 60: $1-46$.

Dorr JVN. 1969. Physiographic, stratigraphic and structural development of the Quadrilátero Ferrífero, Minas Gerais, Brazil. US Geol Surv Prof Pap 110, p. 641-A.

Dorr JVN ANd BARbosa ALM. 1963. Geology and ore deposits of the Itabira district. US Geol Surv Prof Pap 109, p. 341-C.

Dutta BM, Gupta KN and Kapoor AN. 1972. Studies in the macro and microporosities of some Indian ores and their effect on reducibility. Trans of the Indian Inst of Metals 25: 26-32.

ENDO I AND NALINI JR HA. 1992. Geometria e cinemática das estruturas extensionais e compressionais na borda oeste do sinclinal da Moeda, QF. REM Rev Esc de Minas 45: 15-17. 
FeInman J AND MacRae DR. 1999. Direct reduction and reduction smelting terminology. In: FeINMAN J AND MAC RAE D (eds.); Direct Reduction Iron Technology and Economics of Production and Use. Warrendale: Iron and Steel Society, p 225-229.

FIÈs JC AND BRUAND A. 1998. Particle packing and organization of the textural porosity in clay - silt sand mixtures. Eur J Soil Sc 49: 557-567.

GRUNER JW. 1937. Hydrothermal leaching of iron ores of the Lake Superior type - a modified theory. Econ Geol 32: 121-130.

GuILD PW. 1953. Iron deposits of the Congonhas District, Minas Gerais. Econ Geol 48: 639-676.

HARDER EC. 1914. The "itabirite" iron ores of Brazil. Econ Geol 9: 101-111.

Harder EC and Chamberlin RT. 1915. The geology of central Minas Gerais, Brazil. Jour Geol Part I 23: 341-378 and Part II 23: 385-424.

JAMES HL. 1954. Sedimentary facies of iron formations. Econ Geol 49: 236-293.

Klein C And Beukes NJ. 1992. Proterozoic ironformation. In: KondIE KC (ed.); Proterozoic crustal evolution, Amsterdam: Elsevier, p. 383-418.

Kopfle JT. 1999. Direct reduction's place in the world steel industry. The world steel industry - dinosaur or Phoenix? In: Feinman J And Mac Rae D (eds.); Direct Reduction Iron - Technology and Economics of Production and Use. Warrendale: Iron and Steel Society, p. 1-17.

LAGOEIRO LE. 1998. Transformation of magnetite to hematite and its influence in the dissolution of iron oxide minerals. J Met Geol 16: 415-423.

Leone RD, Piancino EJ, Montoro A, Gonzales JM, Grassi RC AND Etchevarne PR. 1981. Evaluacion tecnica de minerales calibrados para reduccion directa. In: VI SEMINARIO ILAFA DE REDUCCION y Fusion Directa, VI, Buenos Aires, 1981. 57p.

Machado N, Noce CM, Ladeira EA and Belo DE Oliveira O. 1992. U-Pb geochronology of Archean magmatism and Proterozoic metamorphism in the Quadrilátero Ferrífero, southern São Francisco craton, Brazil. Geol Soc Am Bull 104: 1221-1227.

Marshak S And Alkmim FF. 1989. Proterozoic contraction/extension tectonics of the southern São Francisco region, Minas Gerais, Brazil. Tectonics
8: 555-571.

Melfi AJ, Pedro G, Nalovic L and Queiroz Neto JP. 1976. Étude sur l'altération géochimique des itabirites du Brésil. Dissolution du quartz et instabilité de l'hématite primaire en conditions tropicales hydrolisantes. Cah ORSTOM Sér Pédol 14: 179192.

MIDREX. 1999. World DRI production increases two percent (March 8 1999).

www. midrex.com/main/recentnews.htm.

Monnier G, Stengel P And Fiès JC. 1973. Une méthode de mesure de la densité apparente de petits aglomérats terreux. Application à l'analyse des systémes de porosité du sol. Ann Agronomiques 24: 533-545.

MorRIs RC. 1980. A textural and mineralogical study of the relationship of iron ore to banded iron-formation in the Hamersley Iron Province of Western Australia. Econ Geol 75: 184-209.

MORRIS RC. 1985. Genesis of iron ore in iron-formation by supergene and supergene-metamorphic processes - A conceptual model. In: Wolf KH (ed.); Handbook of strata-bound and stratiform ore deposits 13, Amsterdam, Elsevier: p. 73-235.

Muniz GL, Santiago TC, Marino F and Rosa RL. 1992. Efeito da Textura e da granulometria do "lump ore"' no processo de redução direta. In: CoNGRESSO AnUAl DA ABM, 47, Belo Horizonte, ABM, 1992, p. 239-258.

Pomerene JB. 1964. Geology and ore depositis of the Belo Horizonte, Ibirité and Macacos Quadrangles, Minas Gerais, Brazil. US Geol Surv Prof Paper 84, p. 341-D.

Poveromo JJ And Swanson AW. 1999. Iron-bearing raw materials for Direct Reduction. In: FEINMAN J AND MAC RAE D (eds.); Direct Reduction Iron Technology and Economics of Production and Use. Warrendale: Iron and Steel Society, p. 59-79.

Powell CMcA, Oliver NHS, Li ZX, Martin DMcB AND RoNASZECKI J. 1999. Synorogenic hydrothermal origin for giant Hamersley iron oxide ore bodies. Geology 27: 175-178.

Ramanaidou E, Nahon D, Decarreau A and Melfi AJ. 1996. Hematite and goethite from duricrusts developed by lateritic chemical weathering of Precam- 
brian banded iron formations, Minas Gerais, Brazil. Clays and Clay Minerals 44: 22-31.

SANDERS BH. 1933. Iron ores at Itabira Brazil. Inst of Min and Met Bull 396: 1-23.

SiKabin J. 1980. Development of direct reduction in the iron and steel industry. In: STEPHENSON RL AND SMailer RM (eds.); Direct Reduced Iron - Technology and Economics of Production and Use. Warrendale: Iron and Steel Society, p. 3-7.

Sills ID, Aylmore LAG AND QUIRK JP. 1973. A comparison between mercure injection and nitrogen sorption as methods of determining pore size distributions. Soil Sci Soc Am Proc 37: 535-537.

VArajão CAC, Ramanaidou E, Colin F and Nahon D. 1996. Martitização: Alteração Supergênica da Magnetita. REM Rev Esc Minas 50: 18-20.
VARajão CAC, Ramanaidou E, COLIN F AND NAHON D. 1997. Gênese dos corpos de hematita compacta "'hard hematite ores'": metassomatismo, sedimentação ou alteração supergênica? REM Rev Esc Minas 50: 40-43.

Varajão CAC, Colin F, Vieillard P, Melfi AJ And NAHON D. 2000. Early Weathering of Palladium Gold under Lateritic Conditions, Maquiné Mine, Minas Gerais, Brazil. Appl Geoch 15: 245-263.

Xavier E de M. 1994. Relação entre o processo de redução direta e os atributos estruturais e texturais do minério de ferro granulado da Mina da Mutuca, Belo Horizonte, MG. MSc Thesis, UFOP - University Federal of Ouro Preto, Brazil, 164p.

Zavaglia G. 1996. Condicionantes geológicos do comportamento dos minérios de ferro do depósito de Tamanduá (MG) no processo metalúrgico de redução direta. MSc Thesis, UFOP - University Federal of Ouro Preto, Brazil, 200p. 